\title{
Productivity and costs of two low-investment biomass harvesting systems applied in a situation of mixed forest of semi-natural regeneration
}

\author{
Productividad y costos de dos sistemas de aprovechamiento de biomasa de baja inversión \\ aplicados en una condición de bosque mixto de origen seminatural
}

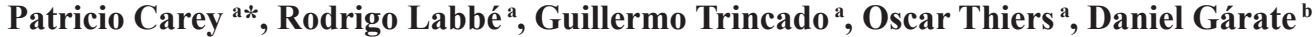 \\ *Corresponding author: ${ }^{a}$ Universidad Austral de Chile, Faculty of Forest Sciences and Natural Resources, \\ Institute of Forest and Society, tel.: 56-63-2293002, pcarey@uach.cl \\ ${ }^{\mathrm{b}}$ Universidad Austral de Chile, Valdivia, Chile.
}

\begin{abstract}
SUMMARY
This study identifies the most influential variables in harvesting operations and compares the productivity and costs of two lowinvestment biomass harvesting system for young trees, likely to be used by owners of small and medium-sized forests in south-central Chile. The focus is harvesting the natural regeneration of Acacia melanoxylon, characterized by a high density, around 6,900 trees ha-1, with an average diameter at breast height (DBH) of 5.5 centimeters, under the cover of a Eucalyptus globulus plantation established in 2004 in Valdivia, Los Ríos region, Chile. Whole-tree harvesting was used and included felling and skidding activities. In the motor-manual system, felling was carried out with chainsaws and skidding with oxen. In the semi-mechanized system, two chainsaws equipped with a felling frame and a farm tractor with grapple for skidding were used. Time studies were done, productivity models were developed and harvesting costs were calculated. The cost of both harvesting systems was relatively similar, for an 80-meter average skidding distance, with an average cost of $24.7 \mathrm{USD} \mathrm{Mg}_{\mathrm{w}}{ }^{-1}$ (wet weight) in the motor-manual system and $24.0 \mathrm{USD} \mathrm{Mg}_{\mathrm{w}}{ }^{-1}$ in the semi-mechanized system. Understory density and terrain slope had a highly significant impact on productivity and felling costs. For skidding, the hauling distance and skidding capacity significantly affected productivity and costs, while terrain slope, with ranges between 0 and $20 \%$, had no significant effects on productivity.
\end{abstract}

Key words: Acacia melanoxylon, Eucalyptus globulus, forest biomass, young trees, small and medium-sized forests.

\section{RESUMEN}

Este estudio identifica las variables de mayor influencia en operaciones de aprovechamiento y compara la productividad y costos de dos sistemas de aprovechamiento de biomasa de baja inversión para árboles jóvenes, susceptibles de ser utilizados por pequeños y medianos propietarios forestales del centro-sur de Chile. El estudio se enfocó en el aprovechamiento de la regeneración natural de A. melanoxylon caracterizada por una alta densidad, alrededor de 6.900 árboles ha-1 ${ }^{-1}$ con un diámetro medio (DMC) de 5,5 cm, bajo la cobertura de una plantación de E. globulus establecida el año 2004 en Valdivia, región de Los Ríos, Chile. El aprovechamiento fue de árbol completo e incluyó las actividades de volteo, extracción y apilado a orilla de camino. En el sistema manual, el volteo se realizó con motosierra y la extracción con bueyes. En el sistema semimecanizado se utilizaron dos motosierras equipadas con un marco de volteo y un tractor agrícola con garra para extracción. Se realizaron estudios de tiempo, se desarrollaron modelos de productividad y se calcularon los costos. Para una distancia de extracción de 80 metros, distancia promedio de madereo, los costos totales fueron de 24,7 USD $\mathrm{Mg}_{\mathrm{w}}{ }^{-1}$ (toneladas húmedas) en el sistema manual y de 24,0 $\mathrm{USD} \mathrm{Mg}_{\mathrm{w}}{ }^{-1}$ en el sistema semimecanizado. La densidad del sotobosque y la pendiente del terreno tuvieron una incidencia altamente significativa en las productividades y costos del volteo. En extracción, la distancia y el tamaño de carga afectaron significativamente las productividades y costos; la pendiente, dentro de un rango de 0 a $20 \%$, no tuvo efectos significativos sobre la productividad.

Palabras clave: Acacia melanoxylon, Eucalyptus globulus, biomasa forestal, bioenergía, pequeños y medianos propietarios.

\section{INTRODUCTION}

In south-central Chile, forest biomass has a high potential to be used for energy purpose, for example, to supply power plants, co-generation plants and district heating plants without affecting the required biomass to supply the traditional uses of urban and rural heating (Ministerio de Energía et al. 2012). The high potential of forest biomass is due to the large area of native forest available for energy purposes, estimated in more than 2.8 million hectares between Biobío and Los Lagos Regions, where the biomass from the silvicultural management of second-growth 
native forests has special potential (Ministerio de Energía et al. 2012); also from the use of residues from forest plantations (Acuña et al. 2017), and the available soils with potential for the establishment of energy crops, estimated in 427,000 hectares between Biobío and Los Lagos Regions under an agricultural safeguard scenario (Ministerio de Energía et al. 2012).

To achieve the potential that forest biomass offers as a source of renewable energy in south-central Chile, the development of a supply chain that meets the quality requirements and is stable and safe over time is required. This is fundamental to the implementation of energy projects in the long-term. The biomass supply chain for wood chips includes growth phases, harvesting (felling and skidding), pre-treatment (drying and chipping) and transportation to the energy plant (Alakangas and Virkkunen 2007). Harvesting and pre-treatment phases are considered critical, since these present a high complexity from a technical point of view and make up the largest share of the cost of the biomass supply chain (Hakkila 2005, Kofman and Kent 2007, Alakangas and Virkkunen 2007).

Regarding the harvesting phase, one of the biggest technical complexities is related to the characteristics of the forest biomass that is used for energy purposes, which many times is presented in the form of young trees or forest residues of varied volumes (Francescato et al. 2009, Con$\mathrm{rad}$ et al. 2013). As a result, many times conventional forest harvesting systems are oversize for the characteristics of biomass or inadequate for ergonomic problems (Laitila 2008). Thus, it becomes necessary to technically analyze the other harvesting systems' configurations, implemented at local level, which may be adequate for the characteristics of biomass and the terrain conditions as support for planning and decision-making (Acuña et al. 2017).

Numerous studies conducted in North America and Europe have been focused on the evaluations of high-investment systems designed for harvesting biomass for energy purposes through short rotation coppice (SRC) (Spinelli et al. 2009, Fiala and Bacenetti 2012) and from early or pre-commercial thinning in plantations as well as in natural forests, composed by species of conifer and broadleaf trees (Kofman and Kent 2007, Laitila 2008). In these studies, the systems used are designed for the harvesting of small-sized trees (trees with diameters at breast height (DBH) of 3 to $15 \mathrm{~cm}$ ), are characterized by their high level of mechanization and are used for medium to large-scale work with the purpose of reducing costs and increasing harvesting productivity.

Unlike high-investment harvesting systems, lowinvestment harvesting systems are characterized by high use of labor and a low level of mechanization, designed for small-scale harvesting (Carey et al. 2006). According to Alakangas and Virkkunen (2007), in Northern Europe, low-investment harvesting systems are used for early or pre-commercial thinning for wood chips production from small-sized trees. Woodchips are generally used as supplies for small plants that provide heating for districts or large buildings $(<1 \mathrm{MWh})$, where biomass quality plays an important role. Whole-tree harvesting is the most efficient method, since the cutting and clearing of trees considerably elevates the cost (Kofman and Kent 2007, Laitila 2008). Likewise, the delimbing of small trees decreases their energy potential, and as a result, the cost of woodchips is increased (Hakkila 2005).

Although the harvesting equipment can vary in different studies, with low-investment harvesting systems, tree felling is done using chainsaws equipped with a felling frame whose purpose is to improve efficiency and reduce physical workload. Cut trees are piled and stored inside the forest for as long as a season to reduce their moisture content to under $30 \%$ (wet basis). Later, these are extracted to the roadside using farm tractors conditioned for biomass skidding, where finally they are chipped and transported in trucks or tractors with containers for woodchips, depending on the transportation distance (Alakangas and Virkkunen 2007). With these harvesting systems, tree size, the presence of weeds or shrubs and terrain slope have a high impact on productivity and felling costs (Kofman and Kent 2007, Laitila 2008, Francescato et al. 2009). Regarding skidding, productivities and costs vary according to the quantity of biomass accumulated in the stand, hauling distance, and the skidding capacity of used machinery (Kofman and Kent 2007, Alakangas and Virkkunen 2007).

In Chile, low-investment biomass harvesting systems adapted to local conditions have a high potential to be used by owners of small and medium-sized forests; for example, for thinning in native forest of second growth with small-sized trees, in pre-commercial thinning in plantations and in situations with mixed forest of semi-natural regeneration characterized by abundant natural regeneration of Acacia spp. within forest plantations. This last situation of abundant natural regeneration of Acacia spp. under the canopy of native forests and forest plantations is frequent in the south of Chile given its fast growth, high competitiveness with other species and growth capacity in semi-shade conditions (Siebert and Cerda 1994).

The hypothesis of this research is that the harvesting of the natural regeneration of Acacia melanoxylon $\mathrm{R}$. Br. for energy use, below the cover of a forest plantation, is technically and economically feasible by using low-investment harvesting systems. The General Objective is to identify the most influential variables during the harvest of the natural regeneration of $A$. melanoxylon under the cover of a Eucalyptus globulus Labill plantation and provide information about productivity and cost of two lowinvestment harvesting systems. Specific objectives are: 1) to identify the most influential variables acting on the productivity and cost of the harvest under the conditions of the study, and 2) to compare, under similar operating conditions, the performance of two low-investment harvesting systems. 


\section{METHODS}

Description of the location of the study. The study was carried out in Las Palmas ( $\left.39^{\circ} 44^{\prime} 50^{\prime \prime} \mathrm{S}-73^{\circ} 08^{\prime} 50^{\prime \prime} \mathrm{O}\right)$, a property of Universidad Austral de Chile. Las Palmas is located $20 \mathrm{~km}$ north of Valdivia city, Los Rios Region, Chile. According to the Köppen classification, the climate is temperate rain with Mediterranean influence (Donoso 2008). Annual precipitation is around $1,900 \mathrm{~mm}$, concentrating in winter months (May to August) and there are occasional summer droughts. The average annual temperature is between 9 and $12{ }^{\circ} \mathrm{C}$. Soils derive from ancient volcanic ash and other wind deposits, which correspond to red clay soils of Los Ulmos series, Typic Paleudults (CIREN 2001).

The stand corresponds to a plantation of E. globulus established in 2004 with abundant natural regeneration of A. melanoxylon. The stand possesses a total surface of 3.8 hectares. The harvesting of $A$. melanoxylon was done on a surface of three hectares approximately. This surface was divided into two harvesting sectors, each sector with an approximate surface of 1.5 hectares. The remaining area was conserved as a witness sector with no intervention.

Forest stand parameters. The forest parameters were obtained from a set of eight temporary plots, with four plots per each harvesting sector. Concentric plots were established with a surface area of $500 \mathrm{~m}^{2}$ for E. globulus and $100 \mathrm{~m}^{2}$ for measurement of the natural regeneration of A. melanoxylon. In each sector, pre-harvesting inventories were conducted. The inventory in the motor-manual harvesting sector was done in November 2011 and the semi-mechanized harvesting sector in January 2013. For E. globulus, the diameter at breast height (DBH) and five heights per plot were recorded. For $A$. melanoxylon, the DBH of all the trees with a DBH $>3 \mathrm{~cm}$ and five heights per plot were recorded. With the DBH and height measurements, the stand tables of both species and also those with only E. globulus were done for each harvesting sector. By considering the section without bark and a usage rate of $6 \mathrm{~cm}$, the commercial volume per hectare of E. globulus was estimated through the function of adjusted tapering for this species and zone (Norambuena 1996) (table 1).

Aerial biomass estimates of A. melanoxylon. The aerial biomass weight of $A$. melanoxylon was estimated using allometric functions (table 2). Functions were adjusted through 31 samples (trees) cut from the $100 \mathrm{~m}^{2}$ plots (average of 4 trees per plot with 16 and 15 trees for the motormanual harvesting sector and semi-mechanized harvesting sector, respectively). These functions estimate the wet weight $(\mathrm{kg})$ for stem biomass component $(\mathrm{SB})$, for crown biomass component (branches plus leaves) (CB), and the total aerial weight of the tree through the sum of the two components $(\mathrm{SB}+\mathrm{CB})$. The estimates to units of weight per hectare were done at the diametric class level in terms

Table 1. Description of the location of the study. Inventory data: area with motor-manual harvesting, November 2011; area with semimechanized harvesting, January 2013.

Descripción de los dos sectores de aprovechamiento de biomasa. La plantación de E. globulus fue establecida el año 2004. Fechas de inventario: sector con aprovechamiento manual, noviembre 2011; sector con aprovechamiento semimecanizado, enero 2013.

\begin{tabular}{|c|c|c|c|}
\hline \multicolumn{2}{|c|}{ Description } & $\begin{array}{c}\text { Area with motor-manual } \\
\text { harvesting }\end{array}$ & $\begin{array}{c}\text { Area with semi- } \\
\text { mechanized harvesting }\end{array}$ \\
\hline \multicolumn{2}{|l|}{ Surface (ha) } & 1.52 & 1.58 \\
\hline \multicolumn{2}{|l|}{ Average slope (\%) } & 13 & 16 \\
\hline \multirow{4}{*}{$\begin{array}{l}\text { Eucalyptus globulus } \\
\text { (established in 2004) }\end{array}$} & Stocking (trees ha-1) & 740 & 770 \\
\hline & Average DBH $(\mathrm{cm})$ & 15.7 & 17.0 \\
\hline & Mean height (m) & 18.6 & 19.3 \\
\hline & Stem volume $\left(\mathrm{m}^{3}\right.$ solid $\left.\mathrm{ha}^{-1}\right)$ & 95.1 & 108.1 \\
\hline \multirow{6}{*}{ Acacia melanoxylon } & Stocking (trees ha-1) & 6,900 & 6,850 \\
\hline & Average DBH $(\mathrm{cm})$ & 5.3 & 5.6 \\
\hline & Mean height (m) & 9.9 & 10.3 \\
\hline & Wet weight $\left(\mathrm{Mg}_{\mathrm{w}} \mathrm{ha}^{-1}\right)$ & 96.2 & 124.6 \\
\hline & Moisture content (\%) & 42.8 & 46.0 \\
\hline & Dry weight $\left(\mathrm{Mg}_{\mathrm{d}} \mathrm{ha}^{-1}\right)$ & 52.0 & 67.3 \\
\hline
\end{tabular}

Mg: megagram is equal to a ton. 
of wet weight $\left(\mathrm{Mg}_{\mathrm{w}} \mathrm{ha}^{-1}\right)$ and dry weight $\left(\mathrm{Mg}_{\mathrm{d}} \mathrm{ha}^{-1}\right)$, considering the total height $(\mathrm{m})$ and the $\mathrm{DBH}(\mathrm{cm})$ as predictor variables and the moisture content of the biomass. Moisture content was determined from three random samples per harvesting sector, each one of approximately $300 \mathrm{~g}$ composed by wood disks of the stem, branches and leaves and obtained from the trees cut on the $100 \mathrm{~m}^{2}$ plots. Their moisture content was determined in the laboratory by the oven drying method according to the Chilean Standard $\mathrm{NCH}$ 176/1.

Description of harvesting systems. The whole tree harvesting method was used and includes felling and piling of small size trees, and skidding to the roadside (figure 1):
- Motor-manual harvesting system: included an operator with a chainsaw Stihl MS 360 (model usually used for felling in traditional forest harvest) in charge of cutting all trees of $A$. melanoxylon plus a helper to assist in the release of the cut trees and stack them in bundles (figure 1A). The skidding of bundles was carried out by two oxen (figure 1B). At the time of harvesting, the oxen had four years of age, an average weight of $500 \mathrm{~kg}$ per ox and two years of training in $\log$ extraction. Both activities were realized simultaneously during December 2011.

- Semi-mechanized harvesting system: in the semimechanized harvesting system, felling was performed by two operators in February 2013. Each operator

Table 2. Allometric functions used for the aerial biomass estimate wet weight (kg) of Acacia melanoxylon. Coefficients with $95 \%$ confidence intervals (in parentheses).

Funciones alométricas utilizadas para la estimación de la biomasa aérea de Acacia melanoxylon. Coeficientes con intervalos a un $95 \%$ de confianza (en paréntesis).

\begin{tabular}{lrrrr}
\hline & \multicolumn{1}{c}{$b_{1}$} & \multicolumn{1}{c}{$b_{2}$} & \multicolumn{1}{c}{ Function } & $\mathrm{R}^{2}$ \\
\hline \multirow{2}{*}{ Stem } & -3.1978 & 0.9867 & $\ln (\mathrm{SB})=-3.1978+0.9867 \ln \left(\mathrm{DBH}^{2} \mathrm{H}\right)$ & $0.9831 * * *$ \\
& $(-3.5006 ;-2.8950)$ & $(0.9375 ; 1.0358)$ & & \\
\multirow{2}{*}{ Crown } & -5.2608 & 1.1220 & & \\
& $(-5.9234 ;-4.5982)$ & $(1.0144 ; 1.2296)$ & & \\
\end{tabular}

ln: natural logarithm; DBH: diameter at breast height $(\mathrm{cm})$; H: total height $(\mathrm{m}) ; \mathrm{R}^{2}$ : coefficient of determination; $* * *=P<0.001$.

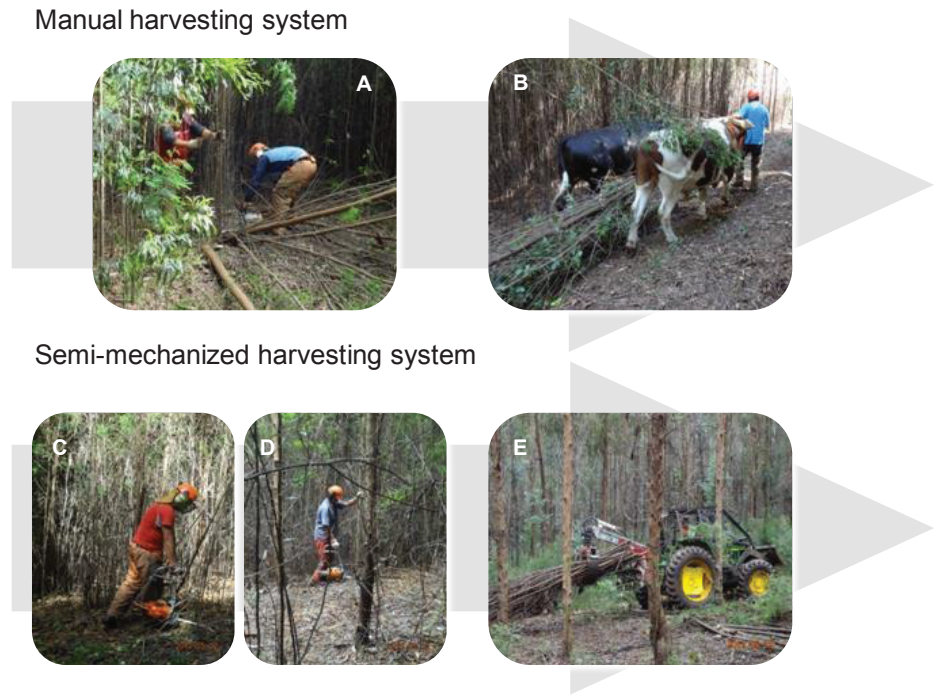

Figure 1. Harvesting system for biomass production. A) Operator with Stihl MS 361 chainsaw plus an assistant. B) Skidding with oxen. C) Operator with Stihl MS 260 chainsaw and felling frame. D) Operator with Husqvarna 440e chainsaw and felling frame. E) Skidding with John Deere 6403 farm tractor, with grapple.

Sistemas de aprovechamiento de biomasa. A) Operador de motosierra Stihl MS 361 más un ayudante para desenganche y apilado. B) Extracción de gavillas con bueyes. C) Operador de motosierra Husqvarna 440e con marco de volteo. D) Operador de motosierra Stihl MS 260 con marco de volteo. E) Extracción de gavillas con tractor John Deere 6403. 
worked independently, cutting all trees and stacking them in bundles. Operator 1 was equipped with a Husqvarna 440e chainsaw (figure 1C) and operator 2 was equipped with a Stihl MS 260 chainsaw (figure 1D). Both chainsaws were equipped with a felling frame of Finish origin designed to cut small size trees (Apuri felling handle 2010). Skidding was conducted in May 2013, by a John Deere 6403 four-wheel drive farm tractor, with a grapple and conditioned for forest works (figure 1E).

All workers were contractors with experience in traditional forest operations.

Productivity study. During harvesting, time-motion studies were performed differentiating the following concepts described by Brinker et al. (2002):

- Scheduled work hour (SWH): is the time during which machinery and workers are scheduled to do productive work, including delaying time. That is equivalent to the amount of uptime and delays.

- Productive work hour (PWH): is the part of the scheduled time during which machinery and workers are performing their scheduled function (excluding delays).

- Delays: occasional times, whether indirectly productive or dead time. These were classified into three groups: operational, mechanical and personal.

The number of observations done of both felling as well as skidding was calculated to comply with a maximum sampling error of $10 \%$ with $95 \%$ reliability (Prodan et al. 1997) (table 3).

For felling, because times were too short to register every tree cut, a continuous time measurement was used with 15-minute observations and a 5-minute break between observations. In each observation, for each operator with a chainsaw, their productive times, delays and number of trees cut were recorded. The latter was done by using a manual counter. The felling productivity per productive work hour was calculated for each observation with the formula [1] adapted from Conrad et al. (2013).

$$
\begin{gathered}
\text { Felling productivity }\left(\mathrm{Mg} \mathrm{PWH}^{-1}\right)= \\
\frac{\text { number of trees per observation } \times \mathrm{Mg} \text { per tree }}{\text { productiver time per observation }(\mathrm{h})(\text { excluding delays })}
\end{gathered}
$$

Additionally, in the semi-mechanized system, terrain slope and understory density were measured, since in this harvesting area, a superior topographic variation was observed as well as changes in understory density due to the presence of sectors without E. globulus cover. To do so, both variables were classified into low, medium and high in each observation (table 4). Understory densities were classified visually and terrain slope by means of a clinometer. Both cases represent the dominant work situation during each observation.

In skidding, the time of each work cycle was registered, which includes: empty trip from the roadside to the forest, biomass load, trip with load from the forest to the roadside, unloading of biomass and delays (Carey et al. 2006). Each work cycle was associated with a skidding

Table 4. Criteria used for the classification of understory density of $A$. melanoxylon trees with diameters $<3 \mathrm{~cm}$, and terrain slope in felling activity.

Criterios utilizados para la clasificación de la densidad de sotobosque y pendiente del terreno en la actividad de volteo.

\begin{tabular}{lcc}
\hline Classification & $\begin{array}{c}\text { Understory density } \\
\text { (\% cover) }\end{array}$ & $\begin{array}{c}\text { Terrain slope } \\
(\%)\end{array}$ \\
\hline Low & $<25$ & 0 to 10 \\
Medium & $25-75$ & 11 to 20 \\
High & $>75$ & 21 to 30 \\
\hline
\end{tabular}

\begin{tabular}{|c|c|c|c|c|c|}
\hline \multicolumn{3}{|c|}{ Harvesting system } & $\begin{array}{l}\text { Number of } \\
\text { observations }\end{array}$ & $\begin{array}{c}\text { Total time of } \\
\text { observation }(\mathrm{h})\end{array}$ & $\begin{array}{l}\text { Sampling } \\
\text { error (\%) }\end{array}$ \\
\hline \multirow{2}{*}{ Motor-manual } & Felling & & 172 & 43 & 6.5 \\
\hline & Skiddin & & 351 & 40 & 3.5 \\
\hline \multirow{3}{*}{ Semi-mechanized } & \multirow{2}{*}{ Felling } & Operator 1 & 184 & 46 & 4.0 \\
\hline & & Operator 2 & 257 & 64 & 4.3 \\
\hline & \multicolumn{2}{|c|}{ Skidding } & 74 & 21 & 7.6 \\
\hline
\end{tabular}

Table 3. Number of observations per harvesting system and associated sampling error.

Número de observaciones por sistema de aprovechamiento y error de muestreo asociado.

Operator 1: operator with Husqvarna 440e chainsaw; Operator 2: operator with Stihl MS 260 chainsaw. 
distance measured with an odometer and an average slope of the route determined with a clinometer. Likewise, the number of trees from the extracted bundle was recorded. The trees from the bundles that were left without being extracted, which was considered a loss, were also recorded. The skidding productivity per productive work hour was calculated for each work cycle with the formula [2] adapted from Conrad et al. (2013).

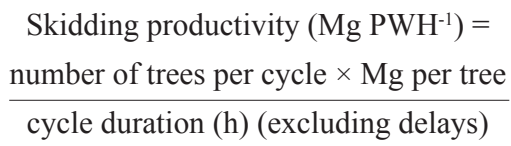

Following skidding, a new inventory was done to quantify possible damage to the E. globulus trees.

The weight in $\mathrm{Mg}$ per tree used in the formulas [1] and [2] only considers stem biomass, since it is assumed that once in open space and during the drying process before being piled, trees lose their leaves. Moreover, branches, because of their small diameter $(<3 \mathrm{~cm})$, define the proportions of rejected woodchips, since it reduces biomass quality as prime material for energy use (Pari et al. 2013). Biomass per tree was calculated in wet weight $\left(\mathrm{Mg}_{\mathrm{w}}\right)$ and dry weight $\left(\mathrm{Mg}_{\mathrm{d}}\right)$ with biomass functions adjusted for the stem component (table 2). They also represent the tree with average diameter squared of the corresponding harvesting sector (table 1). Productivity per scheduled work hour $\left(\mathrm{Mg}_{\mathrm{w}} \mathrm{SWH}^{-1}\right.$ or $\left.\mathrm{Mg}_{\mathrm{d}} \mathrm{SWH}^{-1}\right)$ was obtained multiplying productivity per productive work hour by use rate (ratio of productive time to scheduled time) (Brinker et al. 2002).

Study cost. The study cost was carried out through Miyata's methodology (1980). All costs and prices are indicated in United States dollars (USD) using a dollar value of 620 CLP (Banco Central de Chile October 23, 2017). The assumed recovery value was $20 \%$ of the buying price for each piece of equipment, and $60 \%$ of the buying price for oxen (Rodríguez 1984). An interest rate of $10 \%$ of the annual average investment was considered, plus $5 \%$ corresponding to taxes and insurances, with 250 working days in a year. The low number of work days per year is due, among other facts, to the frequent occurrence of non-attendance, which is the reality in manual workers for small-scale forest works. The cost of the accessories includes complementary elements to machinery and safety apparel for workers. The workforce cost was determined by the fees paid by contractors to their workers plus $20 \%$ as a social duty. Fuel and lubricant consumption was determined using the data gathered during the study.

All of the harvesting costs were calculated by scheduled machine hour (USD SWH-1). The cost per weight (USD $\mathrm{Mg}^{-1}$ ) resulted from the quotient between the cost per scheduled machine hour (USD $\mathrm{SWH}^{-1}$ ) and the productivity in both wet and dry biomass weight per scheduled machine hour $\left(\mathrm{Mg} \mathrm{SWH}^{-1}\right)$.
Data analyses. The effect of understory density and terrain slope on felling productivity in the semi-mechanized system was evaluated through analysis of variance (ANOVA) [3]. The ANOVA was done using the GLM process. The interaction between the understory density factor and the terrain slope factor was not evaluated because there was not enough data for each combination of levels in both variables. The average values that presented significant differences were compared with the Tukey test $(P<0.05)$.

$$
\gamma_{\mathrm{ijk} l}=\mu+\alpha_{\mathrm{i}}+\beta_{\mathrm{j}}+\chi_{\mathrm{k}}+\varepsilon_{\mathrm{ijk} 1}
$$

Where:

$$
\begin{aligned}
& \mu=\text { average productivity }\left(\mathrm{Mg}_{\mathrm{w}} \mathrm{PWH}^{-1}\right) \\
& \alpha_{i}=\text { operator factor } \\
& \beta_{j}=\text { understory density factor } \\
& \chi_{k}=\text { slope factor } \\
& \varepsilon_{i j k l}=\text { experimental error }
\end{aligned}
$$

Skidding productivity was estimated with regression models adjusted individually for oxen and for the tractor (Olsen et al. 1998). The database was divided into calibration set $(75 \%$ of data) and a prediction set $(25 \%$ of data). Data were selected for each set at random. The variables included in the models were: skidding distance $(\mathrm{m})$, the average slope of the route $(\%)$ and the number of extracted trees. The adjustment process was done through the Ordinary Least Squares (OLS) method. The adjusted coefficient of determination $\left(\mathrm{R}^{2}\right)$ and the significance of regression coefficients were obtained. Those models that presented at least one insignificant coefficient were discarded. The predictive capacities of the models selected in the previous stage were evaluated through the standard error of prediction (SEP) and bias (Labbé et al. 2013).

All analyses were done with the $\mathrm{R}$ statistics program (R Core Team 2013). In all cases the assumption of normality, homoscedasticity and residual independence was verified.

\section{RESULTS}

Productive times and delays. In felling, the least productive times were observed in the motor-manual system, equivalent to $63.9 \%$ of scheduled work time (figure 2). The main component of delay was rest breaks for operators (personal delays), representing $20.8 \%$ of scheduled work times. The operational delays represented $14.5 \%$, amongst which waiting periods due to simultaneous work with the skidding activity $(6.7 \%)$ stand out. In the semi-mechanized system, productive times for felling represented $77.5 \%$ of scheduled work time. Personal delays for the operators to rest represented only $9.0 \%$, operational delays represented $9.6 \%$, and mechanical delays represented the remaining $3.1 \%$, mainly due to problems with adjusting the felling frame on chainsaws. 


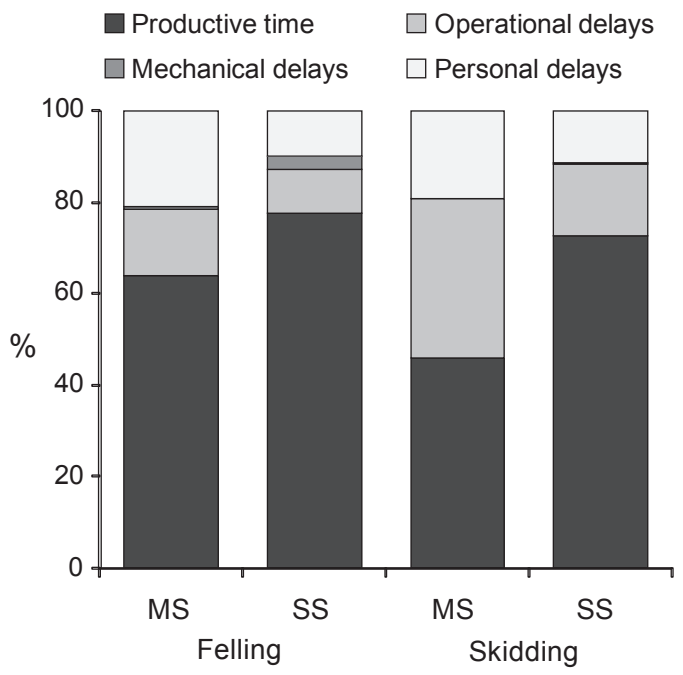

Figure 2. Percentage breakdown of the productive work hour and delay times by harvesting system. MS: motor-manual system; SS: semi-mechanized system.

Distribución porcentual de los tiempos productivos y los tiempos de demoras por sistema de aprovechamiento. SM: sistema manual; SS: sistema semimecanizado.

In skidding, the productive times of the motor-manual system were equivalent to $46.1 \%$ of scheduled work time (figure 2). Personal delays represent $19.0 \%$ of scheduled work time in the motor-manual system, and were due to rest breaks for the operator or oxen. Operational delays consisted of: waiting for bundles to be prepared (14.0\%), the oxen operator's help to make bundles $(8.8 \%)$. The remaining $11.7 \%$ is due to delays during biomass piling. In the semi-mechanized system, productive times for skidding represented $72.7 \%$ of scheduled work time. Rest breaks for the farm tractor operator represent $11.2 \%$ and operational delays $15.6 \%$, of which $6.5 \%$ was during biomass piling, $2.9 \%$ for pauses to pick the bundle to extract, and $2.2 \%$ in securing and adjusting the load. The only mechanical failure represented only $0.3 \%$ of scheduled work time and consisted of a tractor battery failure.
Felling productivity. Without considering delays, the average productivities of felling in the two harvesting systems were very similar, 1.25 and $1.34 \mathrm{Mg}_{\mathrm{w}} \mathrm{PWH}^{-1}$ for the motormanualandsemi-mechanizedsystems, respectively(table 5). In terms of scheduled work time, due to the largest delays occurring during felling in the motor-manual system, its average productivity was $30 \%$ less than in the semimechanized harvesting system, with yields of $0.8 \mathrm{Mg}_{\mathrm{w}}$ $\mathrm{SWH}^{-1}$ and $1.04 \mathrm{Mg}_{\mathrm{w}} \mathrm{SWH}^{-1}$, respectively.

According to these productivities and considering an effective workday as $6.5 \mathrm{SWH}$ (excluding preparation times and the end of the task), felling production in the motor-manual system reached $5.2 \mathrm{Mg}_{\mathrm{w}}$ day-1 (production of one $\mathrm{Mg}_{\mathrm{w}}$ every 75 minutes) and with the semi-mechanized system, $6.8 \mathrm{Mg}_{\mathrm{w}}$ day ${ }^{-1}$ (production of one $\mathrm{Mg}_{\mathrm{w}}$ every 63 minutes). Biomass output in the semi-mechanized sector reached $95.9 \mathrm{Mg}_{\mathrm{w}} \mathrm{ha}^{-1}$. According to this output, around 19 workdays are required for the felling of a hectare with motor-manual system, while approximately 14 workdays are needed with the semi-mechanized system.

In the semi-mechanized system, without considering the delays, operator 1 achieved a productivity of $0.78 \mathrm{Mg}_{\mathrm{w}}$ $\mathrm{PWH}^{-1}$, which was significantly higher $(P<0.001)$ than operator 2's achieved productivity of $0.56 \mathrm{Mg}_{\mathrm{w}} \mathrm{PWH}^{-1}$ (figure 3).

Felling productivities decreased significantly due to increases in understory density $(P<0.001)$ (figure 3$)$. In conditions of medium or high understory density, the biomass productivities $\left(\mathrm{Mg}_{\mathrm{w}} \mathrm{PWH}^{-1}\right)$ were $37 \%$ and $45 \%$, respectively; significantly less than in conditions of low understory density. Terrain slope also significantly affected felling productivity $(P=0.005)$. Although there were not significant differences in productivity with 0 to $20 \%$ slope, with slopes larger than $20 \%$, felling presented $39 \%$ decrease in productivity about low-slope conditions; this being a significant difference.

Skidding productivity. For oxen as well as for the tractor, productivity $\left(\mathrm{Mg}_{\mathrm{w}} \mathrm{PWH}^{-1}\right)$ can be estimated using the skidding distance (D) and the capacity of the quantified load through the number of extracted trees $(\mathrm{N})$ in each work cycle [4].

Table 5. Felling productivity according to the harvesting system. Average \pm standard deviation.

Productividad en volteo según sistema de aprovechamiento. Promedio \pm desviación estándar.

\begin{tabular}{|c|c|c|c|c|c|}
\hline Harvesting system & $\begin{array}{l}\text { Productivity } \\
\left(\mathrm{Mg}_{\mathrm{w}} \mathrm{PWH}^{-1}\right)\end{array}$ & $\begin{array}{l}\text { Productivity } \\
\left(\mathrm{Mg}_{\mathrm{d}} \mathrm{PWH}^{-1}\right)\end{array}$ & $\begin{array}{l}\text { PP } \\
(\%)\end{array}$ & $\begin{array}{l}\text { Productivity } \\
\left(\mathrm{Mg}_{\mathrm{w}} \mathrm{SWH}^{-1}\right)\end{array}$ & $\begin{array}{l}\text { Productivity } \\
\left(\mathrm{Mg}_{\mathrm{d}} \mathrm{SWH}^{-1}\right)\end{array}$ \\
\hline Motor-manual & $1.25 \pm 0.58$ & $0.70 \pm 0.32$ & 63.9 & $0.80 \pm 0.37$ & $0.45 \pm 0.20$ \\
\hline Semi-mechanized & $1.34 \pm 0.59$ & $0.74 \pm 0.33$ & 77.5 & $1.04 \pm 0.46$ & $0.57 \pm 0.25$ \\
\hline
\end{tabular}

Motor-manual system: productivity corresponds to what is achieved by the operator of the chainsaw and the helper who assists in stacking cut trees. Semi-mechanized system: productivity corresponds to the sum of the two operators who work independently, each one with a chainsaw and felling frame. Mg: megagram; $\mathrm{Mg}_{\mathrm{w}}$ : wet biomass; $\mathrm{Mg}_{\mathrm{d}}$ : dry biomass; $\mathrm{PWH}$ : productive work hour; $\mathrm{SWH}$ : scheduled work hour; PP: productivity percentage (ratio of productive time to scheduled time). 


$$
\ln (\operatorname{Prod})=\mathrm{a}-\mathrm{b} \times \ln (\mathrm{D})+\mathrm{c} \times \ln (\mathrm{N})
$$

[4] with $75 \%$ of the data, while the remaining $25 \%$ was used for the validation of the models (figure 4). These functions indicate that productivity decreases with larger skidding distances and increases with the number of extracted trees. Biomass skidding was done within a distance range of 10 to 90 meters with oxen, and 40 to 180 meters with the tractor. Skidding was carried out mainly in low and mediumslope conditions ( 0 to $20 \%$ ). Within this range, the slope did not have a significant effect over skidding productivity, either over oxen $(P=0.404)$ or the farm tractor $(P=0.813)$.

The predictive capacities of the models were evaluated with a total of 88 oxen observations and 19 tractor observations, each equal to one work cycle. A good relation

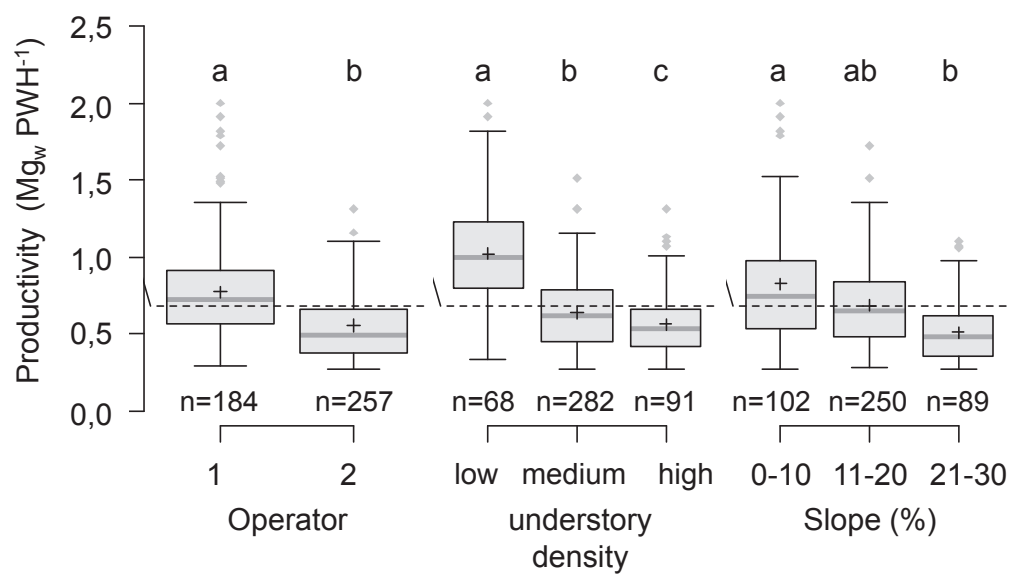

Figure 3. Felling productivity with chainsaw and felling frame according to operator, understory density and slope. Different letters indicate significant differences (Tukey, $P<0.05$ ). Crosses within boxes indicate the average. Horizontal line indicates average felling productivity with chainsaw and felling frame.

Productividad en volteo con motosierra y marco de volteo según operador, densidad de sotobosque y pendiente. Letras diferentes indican diferencias significativas (Tukey, $P<0,05$ ). Cruces dentro de las cajas indican la media. Línea horizontal indica la productividad promedio en volteo con motosierra y marco de volteo.

Table 6. Model of skidding productivity $\left(\mathrm{Mg}_{\mathrm{w}} \mathrm{PWH}^{-1}\right)$ according to logging distance and number of extracted trees. Modelo de productividad en extracción $\left(\mathrm{Mg}_{\mathrm{h}} \mathrm{PMH}^{-1}\right)$ según distancia de madereo y número de árboles extraídos.

\begin{tabular}{|c|c|c|c|c|c|c|}
\hline Variables & Coefficient & Standard error & $P$-value & $\mathrm{R}^{2}$ & $\operatorname{SEP}\left(\mathrm{Mg}_{\mathrm{w}} \mathrm{PWH}^{-1}\right)$ & $\operatorname{Bias}\left(\mathrm{Mg}_{\mathrm{w}} \mathrm{PWH}^{-1}\right)$ \\
\hline \multicolumn{7}{|c|}{ Skidding with oxen } \\
\hline Intercept & 0.14141 & 0.09507 & $0.038 *$ & 0.80 & 0.35 & -0.02 \\
\hline $\ln (\mathrm{D})$ & -0.47433 & 0.01923 & $<0.001 * * *$ & & & \\
\hline $\ln (\mathrm{N})$ & 0.88354 & 0.03750 & $<0.001 * * *$ & & & \\
\hline \multicolumn{7}{|c|}{ Tractor skidding } \\
\hline Intercept & 2.63251 & 0.48258 & $<0.001 * * *$ & 0.70 & 0.57 & 0.06 \\
\hline $\ln (\mathrm{D})$ & -0.86833 & 0.10219 & $<0.001 * * *$ & & & \\
\hline $\ln (\mathrm{N})$ & 0.72366 & 0.07963 & $<0.001 * * *$ & & & \\
\hline
\end{tabular}

ln: logarithm; D: skidding distance in meters; $\mathrm{N}$ : number of extracted trees; $\mathrm{R}^{2}$ : coefficient of determination; $*=P<0.05 ; * * *=P<0.001$; SEP: standard error of prediction. 


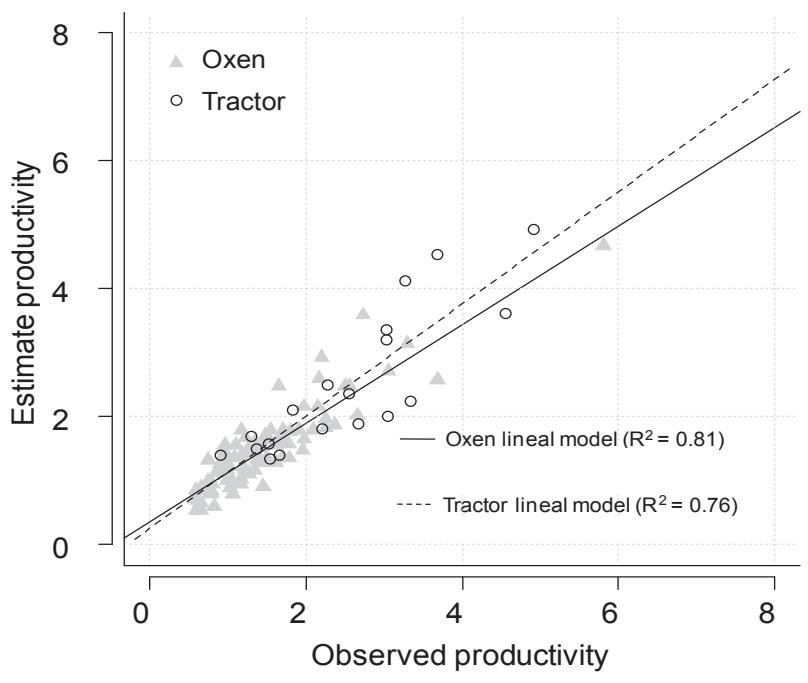

Figure 4. Observed and estimated skidding productivity in wet tons of biomass per productive work hour $\left(\mathrm{Mg}_{\mathrm{w}} \mathrm{PWH}^{-1}\right)$.

Productividad de extracción observada y estimada en toneladas húmedas de biomasa por hora de trabajo productivo $\left(\mathrm{Mg}_{\mathrm{w}} \mathrm{PMH}^{-1}\right)$.

was obtained between the observed (calculated with the formula [2]) and estimated productivity values (table 6) with oxen as well as the tractor $\left(\mathrm{R}^{2}>0.75\right)$ (figure 4). The model for oxen presented the lowest standard error of prediction (SEP). However, the negative bias indicates that the model tends to overestimate skidding productivity. In contrast, the model for the tractor showed a positive bias; therefore, the model underestimates skidding productivity, which is preferable for planning purposes.

Skidding productivity per scheduled time was estimated with the equation [4] multiplied by the utilization rate for oxen $(46.1 \%)$, and the rate for the farm tractor $(72.7 \%)$. Estimated productivities in oxen were lower than those for the farm tractor for the entire range of hauling distances in common (figure 5). However, this difference lessened with larger hauling distances, indicating that the productivity of the farm tractor was more sensitive to increases in the hauling distance.

Harvesting costs. The hourly cost of the motor-manual system was $16.47 \mathrm{USD} \mathrm{SWH}^{-1}$ and in the semi-mechanized system, it was 38.58 USD SWH $^{-1}$ (table 7). Regarding felling, the hourly cost of the motor-manual system was $31 \%$ less than that of the semi-mechanized system. This difference is explained given that in the semi-mechanized system, since felling was carried out by two operators, each one was equipped with a chainsaw with a felling frame, which implies larger investment (fixed cost), higher fuel and lubricant consumption (variable cost) and high workforce cost, because each operator, having the same level of responsibility, was assigned the same income level. Regarding skidding, the hourly cost of the farm tractor

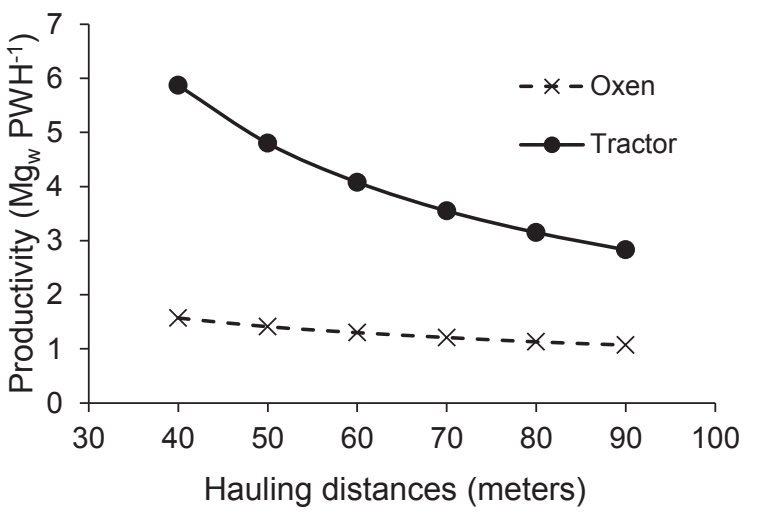

Figure 5. Estimated skidding productivity for different hauling distances.

Productividad estimada en extracción para diferentes distancias de madereo.

per scheduled hour of work was more than 4.1 times larger than that of oxen. These cost differences have the main impact of a significantly superior investment in the tractor, contrasted with oxen (fixed costs), and elevated use of fossil fuel (variable costs).

According to the felling productivities per schedule work hour $\left(\mathrm{Mg}_{\mathrm{w}} \mathrm{SWH}^{-1}\right)$ (table 5), the felling production cost with the motor-manual system was $13.1 \mathrm{USD} \mathrm{Mg}_{\mathrm{w}}{ }^{-1}$ and with the semi-mechanized system, it was 13.2 USD $\mathrm{Mg}_{\mathrm{w}}{ }^{-1}$.

Regarding skidding, the cost comparison was done by simulating productivity through the formula [4] for the whole range of logging distances carried out by oxen and by the tractor (figure 5). The skidding costs per wet biomass ton were larger for the tractor for the entire range of distances in common, when delays are not considered. For example, the skidding cost with oxen and with a farm tractor, for a skidding distance of 40 meters, were, respectively, 3.8 and $4.2 \mathrm{USD} \mathrm{Mg}_{\mathrm{w}}{ }^{-1}$; and for 90 meters, they were 5.6 and $8.8 \mathrm{USD} \mathrm{Mg}_{\mathrm{w}}{ }^{-1}$. Considering delays, skidding costs for the tractor were less than for oxen for the entire range of common distance. For 40 meters, skidding costs for oxen and for the tractor were, respectively, 8.4 and 5.8 USD $\mathrm{Mg}_{\mathrm{w}}{ }^{-1}$ and for a 90 -meter distance, they were 12.3 and $12.0 \mathrm{USD} \mathrm{Mg}_{\mathrm{w}}{ }^{-1}$.

\section{DISCUSSION}

The two biomass harvesting systems presented relatively similar costs. Regarding felling, productivity differences per time of scheduled work between both harvesting systems were conditioned to the occurrence of larger delays in the motor-manual system. These larger delays are explained by the high frequency of rest breaks for the operators that represent more than twice regarding semimechanized system. This decline in delays because of rest 
Table 7. Cost per hour of scheduled work of harvesting systems.

Costos por hora de trabajo planificado de los sistemas de aprovechamiento.

\begin{tabular}{|c|c|c|c|c|}
\hline \multirow{2}{*}{ Cost factor } & \multicolumn{2}{|c|}{ Motor-manual system } & \multicolumn{2}{|c|}{ Semi-mechanized system } \\
\hline & Felling & Skidding & Felling & Skidding \\
\hline \multicolumn{5}{|l|}{ FIXED COSTS $(F C)$} \\
\hline Initial investment (USD) & 779 & 1,813 & 995 & 32,258 \\
\hline Useful life (SWH) & 1,625 & 9,000 & 1,625 & 10,000 \\
\hline Resale value (USD) & 156 & 1,088 & 199 & 6,452 \\
\hline Depreciation (USD SWH'-1) & 0.38 & 0.08 & 0.49 & 2.58 \\
\hline Mean annual investment (USD SWH') & 0.48 & 1.01 & 0.61 & 12.35 \\
\hline Interest, taxes and insurance (USD SWH ${ }^{-1}$ ) & 0.07 & 0.15 & 0.09 & 1.85 \\
\hline Total fixed costs $(C F)\left(\mathrm{USD}_{\mathrm{SWH}}^{-1}\right)$ & 0.45 & 0.23 & 0.58 & 4.43 \\
\hline \multicolumn{5}{|l|}{ VARIABLECOSTS $(V C)$} \\
\hline Fuel consumption $\left(1 \mathrm{SWH}^{-1}\right)$ & 0.32 & - & 0.64 & 6.00 \\
\hline Fuel cost $\left(\mathrm{USD}^{-1}\right)$ & 1.37 & - & 1.37 & 1.05 \\
\hline Lubricant consumption $\left(1 \mathrm{SWH}^{-1}\right)$ & 0.15 & - & 0.42 & 1.00 \\
\hline Lubricant cost (USD 1-1) & 1.63 & - & 1.63 & 1.63 \\
\hline Maintenance and repair (\% of depreciation) (Miyata 1980) & 100 & - & 100 & 100 \\
\hline Main accessory value (USD) & - & - & 485 & 17,581 \\
\hline Useful life (SWH) & - & - & 1,625 & 10,000 \\
\hline Secondary accessories value (USD SWH ${ }^{-1}$ ) & 0.23 & 0.04 & 0.30 & 1.44 \\
\hline Repair and maintenance (USD SWH') & 0.38 & - & 0.49 & 2.58 \\
\hline Fuel $\left(\mathrm{USD} \mathrm{SWH}^{-1}\right)$ & 0.44 & - & 0.88 & 6.29 \\
\hline Lubricant (USD SWH $\left.{ }^{-1}\right)$ & 0.25 & - & 0.68 & 1.61 \\
\hline Accessories (USD SWH $\left.{ }^{-1}\right)$ & 0.23 & 0.05 & 0.84 & 1.62 \\
\hline Food for oxen (USD SWH'-1) & - & 0.38 & - & - \\
\hline Total variable costs $(V C)\left(\mathrm{USD} \mathrm{SWH}^{-1}\right)$ & 1.31 & 0.42 & 2.89 & 13.54 \\
\hline \multicolumn{5}{|l|}{ WORKFORCE $(W F)$} \\
\hline Workday (SWH) & 6.50 & 6.00 & 6.50 & 7.00 \\
\hline Daily operator cost (USD) & 56.5 & 32.26 & 64.5 & 48.39 \\
\hline Workforce $(M O)\left(\mathrm{USD} \mathrm{SWH}^{-1}\right)$ & 8.68 & 5.38 & 9.93 & 6.91 \\
\hline TOTAL HOURLY COST $(F C+V C+W F)\left(\right.$ USD SWH $\left.^{-1}\right)$ & 10.44 & 6.03 & 13.70 & 24.88 \\
\hline
\end{tabular}

breaks for the operators is attributed to the use of chainsaws equipped with felling frames, which permitted a better posture for operators during tree cutting, from an inclined position in the motor-manual system to a standing position in the semi-mechanized system. Moreover, higher productivity per time of scheduled work achieved with chainsaws and felling frames permitted the compensation of its largest hourly cost.

Average felling productivity per operator with a chainsaw and felling frame was $0.29 \mathrm{Mg}_{\mathrm{d}} \mathrm{SWH}^{-1}$ (dry biomass). Applying a wood density of $A$. melanoxylon ${ }^{l}\left(462 \mathrm{~kg} \mathrm{~m}^{-3}\right)$,

\footnotetext{
Wood density of A. melanoxylon in three-year trees with DBH of 3 to $6 \mathrm{~cm}$ (FONDEF B09I1007).
}

the previous productivity equals $0.62 \mathrm{~m}^{3} \mathrm{SWH}^{-1}$. This value is found within the productivity range of felling with a chainsaw and felling frame of 0.4 to $0.7 \mathrm{~m}^{3} \mathrm{SWH}^{-1}$ in short rotation energy crops in Italy (Francescato et al. 2009). The same authors report that these productivities can increase from 0.8 to $1.8 \mathrm{~m}^{3} \mathrm{SWH}^{-1}$ with the scarce presence of weeds and shrubs. In this study, in conditions of low understory density, productivity increased to $1.2 \mathrm{~m}^{3} \mathrm{SWH}^{-1}$, a value slightly lower than the average productivity of 1.5 $\mathrm{m}^{3} \mathrm{SWH}^{-1}$ reported in early or pre-commercial thinning in the north of Europe (Laitila 2008). Terrain slope also had a significant effect on felling productivities. Results indicate that felling with a chainsaw and felling frame presents limitations with slopes larger than $20 \%$. 
In both harvesting systems, the productivity of skidding biomass decreased with longer hauling distances, and for that matter, increased costs (Olsen et al. 1998, Carey et al. 2006, Kofman and Kent 2007, Laitila 2008). Nonetheless, the tractor productivity was more sensitive to the increase in hauling distance. Regarding the above, it should be kept in mind that the biomass extractions carried out in slopes of 0 to $20 \%$ and logging distances up to 90 meters favor the use of oxen (Rodriguez 1984, Carey et al. 2006). In turn, the tractor presented two technical obstacles in relation to operation conditions. The tractor showed maneuvering difficulties in reduced spaces due to its larger dimensions contrasted with oxen, a necessary aspect because biomass extraction was carried out under the cover of the E. globulus plantation. The hydraulic grapple also showed difficulties in grabbing trees of small dimensions as well as skidding capacity in accordance with the lifting capacity of the tractor, established at $3,344 \mathrm{~kg}^{2}$.

In the countries of Northern Europe, farm tractors are equipped with self-loading trailers for biomass extraction, which, based on their largest skidding capacity, can reach productivities of $8 \mathrm{~m}^{3} \mathrm{SWH}^{-1}$ for a 100 -meter logging distance (Alakangas and Virkkunen 2007). In this study, considering the same wood density of A. melanoxylon as in felling, the tractor estimated productivity for a 100-meter logging distance was $2.6 \mathrm{~m}^{3} \mathrm{SWH}^{-1}$. This value is also slightly lower than the range of productivities of 3 to $7 \mathrm{~m}^{3}$ $\mathrm{SWH}^{-1}$ using a tractor and winch for short rotation energy crops in Italy (Francescato et al. 2009).

Oxen sizes were also smaller when compared to studies carried out in Pinus radiata D. Don, where the weight hauled by a team of oxen can reach 1,058 $\mathrm{kg}$ (Rodriguez 1984, Pantaenius 2003). This is attributed to the fact that skidding of trees with low diameters implies transporting a low weight per volume unit. A simple improvement with oxen could be using larger chains that permit the extraction of a larger volume of bundles, with the purpose of compensating for the effect of the low diameter of trees.

In the motor-manual harvesting system, the simultaneous work of felling and skidding activities generated felling delays equal to $6.7 \%$ of the scheduled work time, mainly due to waiting pauses related to tree skidding. With skidding, delays were equal to $25.8 \%$ of the scheduled work time due to pausing to wait for, or to help the oxen operator in making the bundles. Therefore, the development of these activities separately can increase harvesting productivities. Likewise, in the semi-mechanized system, it was found that a three-month separation between felling and skidding activities is sufficient for trees to lose their leaves, in this way decreasing nutrient exportation in the stand (Laitila et al. 2008).

The main limitations of this study are that available biomass as well as operating conditions (topography, understory, plantation cover) are restricted to one location

\footnotetext{
2 John Deere. Specifications of the $6403106 \mathrm{hp}$ model.
}

(case study). Likewise, the design of the two harvesting systems was done according to the availability of personnel, machines and teams at a local level, excluding felling frames, which were imported directly from Finland for the purposes of this study. Therefore, achieved results provide a first evaluation about the energy potential of this biomass and about the use of two low-investment systems for its harvesting, which could perfectly be afforded by small and medium forest owners in central-south Chile. In this sense, it can be concluded that for the operating conditions of this study, for small-scale work, the best alternative consists of a combination of two harvesting systems. The implementation of the felling frame on chainsaws was competitive in terms of cost and permitted the operators to adopt a better posture through an upright position during tree cutting, this was reflected in a decline in delays for rest breaks. On the other hand, skidding distances and terrain slope were adequate for working with oxen. Moreover, these showed a superior versatility regarding operating conditions. Thus, the hypothesis initially posed in this study is not rejected.

\section{CONCLUSIONS}

Biomass harvesting was carried out in a mixed forest situation of semi-natural origin characterized by high density and small-sized trees under the cover of a forest plantation. Under these operating conditions, both lowinvestment harvesting systems reached similar costs; nonetheless, each one with technical problems.

For felling, the use of chainsaws with felling frames helped to decline delays for rest breaks, and hence, increasing productivity per scheduled work time, in this way compensating for its largest hourly cost. Skidding productivity with oxen was less sensitive to the increase in skidding distance, because these showed higher versatility when faced with operating conditions contrasted with farm tractor.

Concerning the variables with the highest influence on harvest operations, understory density and terrain slope had a highly significant impact on productivity and felling costs. For skidding, logging distance and skidding capacity significantly affected productivity and costs, while terrain slope, in a range of 0 to $20 \%$, had no significant effects on productivity.

\section{ACKNOWLEDGMENTS} Chile.

Study Funded by FONDEF B09I1007 (CONICYT),

To the Forest Experimental Center (CEFOR UACh) and in particular to the forest technician Mr. Julián Vázquez for his valuable collaboration in the field work

\section{REFERENCES}

Acuña E, J Cancino, R Rubilar, L Silva. 2017. Volume, physical characteristics and costs of harvest residue utilization of 
Pinus radiata as an energy source. Custos e Agronegócio 13(1): 442-463.

Alakangas E, M Virkkunen. 2007. Biomass fuel supply chains for solid biofuels. Jyväskylä, Finland. EUBIONET2. 32 p.

Apuri felling handle. 2010. Installation and user guide of Apuri felling handle. Consulted 10 Jun. 2012. Available in http:// www.piksa.fi/apurituote/Apuri_FALLINGHANDLE_ eng_01.pdf

Brinker RW, J Kinard, B Rummer, BL Lanford. 2002. Machine rates for selected forest harvesting machines. Auburn University (Alabama Agricultural Experiment Station, Circular 296). Consulted 10 Jul. 2014. Available in https://www. fs.usda.gov/treesearch/pubs/33467

Carey P, A Figueroa, P Valenzuela. 2006. Evaluación técnica de un sistema tradicional de cosecha en plantaciones de $E \mathbf{E}$ calyptus globulus de corta rotación en Valdivia, Chile. Bosque 27(3): 272-276.

CIREN (Centro de Información de Recursos Naturales, CL). 2001. Descripciones de suelos. Materiales y símbolos. Estudio agrológico de la Provincia de Valdivia, Décima Región. Santiago, Chile. CIREN. 196 p.

Conrad J, C Bolding, M Aust, R Smith. 2013. Harvesting productivity and costs when utilizing energy wood from pine plantations of the southern Coastal Plain USA. Biomass and Bioenergy 52: 85-95.

Donoso C. 2008. Ecología forestal: El bosque y su medio ambiente. Sexta edición. Santiago, Chile. Editorial Universitaria. $372 \mathrm{p}$

Fiala M, J Bacenetti. 2012. Economic, energetic and environmental impact in short rotation coppice harvesting operations. Biomass and Bioenergy 42: 107-113.

Francescato V, L Zuccoli, C Metschina, C Schnedl, N Krajnc, N Koscik, G Nocentini, S Stranieri. 2009. Wood fuels handbook. Legnaro, Italy. Italian Agriforestry Energy Association. 83 p.

Hakkila P. 2005. Fuel from early thinnings. International Journal of Forest Engineering 16(1): 11-14.

Kofman PD, T Kent. 2007. Harvesting and processing forest biomass for energy production in Ireland. Dublin, Ireland. The Forest Energy 2006 program (COFORD). 68 p.

Labbé R, F Droppelmann, C Balocchi, M Peredo. 2013. Variation in wood density and pulp yield in Eucalyptus globulus clones evaluated with near infrared spectroscopy. Bosque 34(3): 263-272.

Laitila J. 2008. Harvesting technology and the cost of fuelchips from early thinnings. Silva Fennica 42(2): 267-283.
Ministerio de Energía (Chile), CONAF (Corporación Nacional Forestal, CL), UACh (Universidad Austral de Chile, CL). 2012. Evaluación de mercado de biomasa y su potencial Consulted 10 Jul. 2015. Available in http://sit.conaf.cl/

Miyata ES. 1980. Determining fixed and operating costs of logging equipment. U.S. Department of Agriculture, Forest Service, North Central Forest Experiment Station (General Technical Report NC-55). Consulted in 10 Jun. 2014. Available in https://www.fs.usda.gov/treesearch/pubs/10120

Norambuena A. 1996. Funciones de ahusamiento para plantaciones de Eucalyptus globulus en la provincia de Valdivia, Décima región. Tesis Ingeniero Forestal. Valdivia, Chile. Facultad de Ciencias Forestales, Universidad Austral de Chile. 59 p.

Olsen ED, MM Hossain, ME Miller. 1998. Statistical comparison of methods used in harvesting work studies. Oregon, USA. Oregon State University, College of Forestry, Forest Research Laboratory. 41 p.

Pantaenius P. 2003. Empleo de bueyes en la extracción de raleo de pino: Ensayo comparativo individual y en yunta en plantaciones de la Patagonia. CIEFAP-Patagonia Forestal 9(1): 9-12.

Pari L, V Civitarese, A Del Giudice, A Assirelli, R Spinelli, E Santangelo. 2013. Influence of chipping device and storage method on the quality of SRC poplar biomass. Biomass and Bioenergy 51: 169-176.

Prodan M, R Peters, F Cox, P Real. 1997. Mensura forestal. San José, Costa Rica. Deutsche Gesellschaft für Technische Zusammenarbeit (GTZ) e Instituto Interamericano de Cooperación para la Agricultura (IICA). 561 p. (Serie Investigación y Educación en Desarrollo Sostenible, 1).

R Core Team. 2013. R: A language and environment for statistical computing. R Foundation for Statistical Computing, Vienna, Austria. Consulted 3 Aug. 2015. Available in http:// www.R-project.org/

Rodríguez EO. 1984. Extracción de trozas mediante bueyes y tractores agrícolas. Roma, Italia. Organización de las Naciones Unidas para la Alimentación y la Agricultura (FAO). 104 p. (Estudio de Montes No 49).

Siebert H, JP Cerda. 1994. Aspectos prácticos en la silvicultura de aromo australiano. In Actas del Tercer Taller Silvícola de Fundación Chile. Diversificación y silvicultura: nuevas experiencias. Santiago, Chile. p. 6-16.

Spinelli R, C Nati, N Magagnotti. 2009. Using modified foragers to harvest short-rotation poplar plantations. Biomass and Bioenergy 33: 817-821. 